\title{
In situ boron isotope analysis in marine carbonates and its application for foraminifera and palaeo-pH
}

\author{
Simone A. Kasemann ${ }^{\mathrm{a}, *}$, Daniela N. Schmidt ${ }^{\mathrm{b}}$, Jelle Bijma ${ }^{\mathrm{c}}$, Gavin L. Foster ${ }^{\mathrm{d}}$ \\ a School of GeoSciences, Grant Institute of Earth Science, University of Edinburgh, King's Buildings, West Mains Road, Edinburgh EH9 3JW, United Kingdom \\ ${ }^{\mathrm{b}}$ Department of Earth Sciences, University of Bristol, Wills Memorial Building, Queen's Road, Bristol BS8 1RJ, United Kingdom \\ c Alfred Wegener Institute for Polar and Marine Research, Am Handelshafen 12, 27570 Bremerhaven, Germany \\ d Bristol Isotope Group, Department of Earth Sciences, Bristol University, Wills Memorial Building, Queen's Road, Bristol BS8 1RJ, United Kingdom
}

\section{A R T I C L E I N F O}

\section{Article history:}

Received 30 October 2008

Received in revised form 10 December 2008

Accepted 13 December 2008

Editor: D. Rickard

\section{Keywords:}

Boron isotopes

Reference material

Biogenic carbonates

Proxy

Palaeo-pH

Ion microprobe

\begin{abstract}
A B S T R A C T
The boron isotope composition of marine carbonates such as foraminiferal tests and coral skeletons is increasingly being used to reconstruct seawater $\mathrm{pH}$ values and atmospheric $p \mathrm{CO}_{2}$ concentrations spanning hundreds of thousands or even millions of years. However, inter specific and small scale (microns) intra specific isotopic variation, either due to life processes of an organism or patchy recrystallisation and dissolution in fossilised material, can limit the use of the boron isotope ratio as palaeo-pH recorder. One approach to address this problem is the combined use of in situ and high spatial resolution mass spectrometry and high precision bulk analytical techniques. While much effort has been invested to establish reference material for silicates little attention has been devoted towards characterizing and using carbonate material allowing direct isotopic comparisons between B isotope data produced on carbonates by different techniques and laboratories. Hence, here we present data on the boron isotope composition of carbonate material determined by multicollector inductively coupled plasma mass spectrometry (MC-ICP-MS), thermal ionization mass spectrometry (TIMS), and secondary ionization mass spectrometry (SIMS). The new reference material permits the $\mathrm{B}$ isotope analysis of single foraminiferal chambers using SIMS and to empirically relate between seawater $\mathrm{pH}$, the $\mathrm{B}$ isotope composition of 0 . universa and the predicted foraminiferal vital effect.
\end{abstract}

(C) 2008 Elsevier B.V. All rights reserved.

\section{Introduction}

Chemical signatures of the ambient seawater incorporated in marine carbonates are used to reconstruct past environment and climate conditions. A key challenge for palaeoclimate reconstructions and models is the level of atmospheric carbon dioxide (DeConto and Pollard, 2003). More recently, the impact of rising $\mathrm{CO}_{2}$ in the atmosphere on ocean $\mathrm{pH}$ has been the focus of increasing concern (e.g. Raven et al., 2005). Changes of the alkalinity of the oceans will have important implications on many marine carbonate producers with calcification being impeded progressively as the seawater becomes more acidic. Facing the current anthropogenic increase in $\mathrm{CO}_{2}$, the capability to faithfully reconstruct the past $\mathrm{pH}$ condition of the ocean has become an increasingly important research topic.

Over the last decade a number of studies have demonstrated the great potential of boron as a proxy to study seawater $\mathrm{pH}$ variation and

\footnotetext{
* Corresponding author.

E-mail addresses: simone.kasemann@ed.ac.uk (S.A. Kasemann), d.schmidt@bristol.ac.uk (D.N. Schmidt), Jelle.Bijma@awi.de (J. Bijma), g.l.foster@bristol.ac.uk (G.L. Foster).
}

atmospheric $\mathrm{CO}_{2}$ concentrations (e.g. Spivack and Edmond, 1987; Hemming and Hanson, 1992; Sanyal et al., 1995; Pearson and Palmer, 2000). The speciation of boron and the distribution of the two different isotopes between the different species are sensitive to $\mathrm{pH}$ variations which can produce significant and traceable changes in the isotopic composition of carbonates (Vengosh et al., 1991; Hemming and Hanson, 1992). However, there is debate and concern on how robust and reliable boron isotopes are as a $\mathrm{pH}$ and potential $p \mathrm{CO}_{2}$ proxy (e.g. Pagani et al., 2005; Hönisch et al., 2007).

One substantial uncertainty on the boron isotope based $\mathrm{pH}$ reconstruction can be caused by the isotope fractionation factor used to construct the theoretical $\delta^{11} \mathrm{~B}-\mathrm{pH}$ curve (Pagani et al., 2005; Klochko et al., 2006). However, even with a better established fractionation factor, some of the ocean $\mathrm{pH}$ reconstructions over the Cenozoic using foraminiferal test are unrealistic high and inaccurate for the Quaternary. This could be due to foraminiferal vital effect considerations and assumptions in total dissolved inorganic carbon (DIC) or alkalinity in seawater (see Pagani et al., 2005 for discussion). In addition, poor levels of agreement between different laboratories of the boron isotope composition reported for the same foraminiferal species from similar localities are reported (Foster et al., 2006). One source for the disagreement in the boron isotope composition in marine carbonates 
is due to analytical difficulties. Despite the increase in boron isotope studies and laboratories performing the analyses, the accurate determination of boron isotope compositions in geological materials is still not routine and requires significant analytical skills and a rigorous analytical protocol as demonstrated in the intercomparison work described by Gonfiantini et al. (2003) and Tonarini et al. (2003). In fact, the worst agreement among laboratories was observed for the marine limestone sample.

Another obstacle specifically for the analysis of carbonates is the lack of a suitable certified reference material. So far, the only certified reference material universally used and available for bulk boron isotope analysis is the boric acid NIST SRM 915. Additional reference materials are either seawater or essential silica based materials such as microanalytical glasses, minerals and volcanic rocks all of which are potentially imposing a matrix effect on the analysis depending on the sample preparation (e.g. Kasemann et al., 2001; Tonarini et al., 2003; Rosner and Meixner, 2004).

Further significant uncertainties are caused by vital effects on the boron isotope composition of biogenic carbonates. Foraminiferal tests, coral skeletons and bivalve shells are key components of marine carbonates and an important archive of palaeoclimatic data. As such the $\mathrm{B}$ isotopic composition of the biogenic calcite preserved in marine sediments provides an archive for the $\mathrm{pH}$ of the ocean and is the main target for reconstructions of past atmospheric $\mathrm{CO}_{2}$ concentrations (e.g. Spivack et al., 1993; Sanyal et al., 1995; Palmer et al., 1998; Pearson and Palmer, 2000; Sanyal et al., 2001; Palmer and Pearson, 2003; Hönisch and Hemming, 2004; Ni et al., 2007; Foster, 2008). However, physiological processes, such as respiration, photosynthesis and calcification can modify the micro-environmental $\mathrm{pH}$ in the calcifying region of the organism (e.g. Rink et al., 1998; Wolf-Gladrow et al., 1999; Zeebe et al., 2003) and thus change the B-isotope composition of the carbonate (Rollion-Bard et al., 2003; Zeebe et al., 2003; Blamart et al., 2007). Yet, vital effects do not necessarily compromise the use of $\delta^{11} \mathrm{~B}$ as a palaeo-pH indicator as modelled by Zeebe et al. (2003).

Boron isotope records from corals and bivalves restricted to near shore environments are often not in equilibrium with the atmosphere and hence do not allow to reconstruct atmospheric $\mathrm{CO}_{2}$. The main carbonate producers in the open ocean waters used in palaeoceanographic reconstructions are shallow (mixed layer) dwelling planktic foraminifers. Foraminiferal carbonates provide an additional complication with regards to palaeoenvironmental reconstructions. Depending on the species, ontogenetic depth migration can range from a few tens to several hundreds of meters (Hemleben et al., 1989). Consequently, chambers formed at different water depths, and hence $\mathrm{pH}$ conditions, are likely to have different $\mathrm{B}$ isotope ratios. In addition to this "ontogenetic" calcification, some species secrete an additional layer of so called gametogenic calcite just prior to reproduction (e.g. Bé, 1980; Hamilton et al., 2008). Similar to the $\mathrm{Mg} / \mathrm{Ca}$ (Nürnberg et al., 1996) and Ca isotope ratio (Kasemann et al., 2008), it can not be excluded that these different modes of calcification might also fractionate boron isotopes differently, even under identical environmental conditions. In addition to biological controls on the boron isotope composition in biogenic carbonate, postdepositional processes such as partial dissolution and diagenetic alteration via e.g. exchange with pore water can also alter the original signal (e.g. Vengosh et al., 1991; Ishikawa and Nakamura, 1993; Spivack and You, 1997; Wara et al., 2003).

To make full use of the proxy and to asses the robustness of boron isotope analyses and the precision of the $\mathrm{pH}$ and $\mathrm{pCO}_{2}$ reconstructions we need to better understand the factors that influence the incorporation of boron into biogenic carbonates e.g. thoroughly evaluate the biological aspects of boron isotope incorporation. To tackle these questions a combination of bulk analytical and in situ microanalytical techniques is necessary. Bulk analytical techniques such as thermal ionization mass spectrometry (TIMS) and multicollector inductively coupled plasma mass spectrometry (MC-ICP-MS) provide a high sample throughput and high precision boron isotope data. Generally, these techniques require considerable amounts of sample material for analysis e.g. more than 100 planktic foraminiferal specimens of the same species from ideally a narrow size fraction or pieces of corals ( $3 \mathrm{mg}$ ) (e.g. Hemming and Hanson, 1992; Hönisch et al., 2004; Foster, 2008). In contrast, microanalytical in situ techniques such as secondary ionization mass spectrometry (SIMS) offer the spatial micron scale resolution necessary to target individual organism as well as analyse selected chambers and calcite layers in foraminiferal test, specific annual and even diurnal growth bands in corals and bivalves (RollionBard et al., 2003; Blamart et al., 2007; Kasemann et al., 2008).

In situ boron isotope analyses of biogenic carbonates are still in its infancy, but preliminary studies in coral skeletons and foraminiferal tests revealed significant and systematic B isotopic variations potentially induced by $\mathrm{pH}$ variations at the sites of calcification (Rollion-Bard et al., 2003; Schmidt and Kasemann 2006; Blamart et al., 2007). Such large variations have never been reported using conventional bulk and micro-drill sampling techniques. In addition, preliminary in situ studies on the lithium, carbon, oxygen and calcium isotope composition of biogenic carbonates (Rollion-Bard et al., 2003; Rollion-Bard et al., 2007; Vigier et al., 2007; Kasemann et al., 2008) demonstrate the need and capability of high spatial resolution SIMS to determine the internal isotopic variability and the influence of growth rates, habitat and symbionts on the isotopic composition.

To make full use of in situ boron isotope analyses and its potential to evaluate the nature and extent of boron isotope variation in marine carbonates, we document analytical conditions that offer the necessary spatial resolution but also provide a sufficient analytical uncertainty. We present the boron isotope composition of biogenic and inorganic carbonates that have been measured using bulk analyses (MC-ICP-MS, TIMS) and in situ techniques (SIMS) to allow inter-laboratory and -analytical comparison. Since this material is not commercially available reference material, we also analysed synthetic, silica-rich glass reference materials from the National Institute of Standards and Technology (NIST) for direct comparison. Finally, we apply SIMS to analyse the boron isotope composition of cultured samples of the foraminifer Orbulina universa whose final chamber was completely built in a pH controlled medium (Sanyal et al., 1996, 2001).

\section{Materials and methods}

\subsection{Samples}

The carbonate samples in this study consist of one marine bivalve (KW-T6), two corals (M93-TB-FC-1; PS69/318-1), 2 planktic foraminifers ( 0 . universa) and one inorganic calcite (UWC-1). Sample KW-T6 is a shell fragment of Tridacna gigas from Huon Peninsula, Papua New Guinea, showing diurnal growth increments between 10 and $30 \mu \mathrm{m}$ (night and day respectively; M. Elliot pers. comm. 2008). Sample M93TB-FC-1 is a piece of massive Porites (sp) coral microatoll from the north coast of Papua New Guinea. The sample has been U-series dated to $2.5 \pm 0.4 \mathrm{ka} \mathrm{BP}$ and analysed for oxygen isotopes (Tudhope et al., 2000, 2001). The cold water coral Desmophyllum (sp) PS69/318-1 is from the Pacific sector of the Southern Ocean $\left(69^{\circ} 08.64^{\prime} \mathrm{S}\right.$ and $123^{\circ} 13.35^{\prime} \mathrm{W}$ ), dredged by R.V. "Polarstern" operated by the Alfred Wegener Institute for Polar and Marine Research in 2005 from a water depth between 1480 and $1788 \mathrm{~m}$. O. universa were collected by scuba divers about $11 \mathrm{~km}$ south of La Parguera (Puerto Rico) and cultured at seawater conditions of $\mathrm{pH} 8.2$ and 8.6, and 10 times artificially enhanced $\left(\sim 50 \mu \mathrm{g} \mathrm{g}^{-1}\right)$ boron concentration (Sanyal et al., 2001). The inorganic calcite sample UWC-1 (University of Wisconsin Calcite standard; Graham et al., 1998) is a piece from a $10 \mathrm{~cm}$ cleavage rhomb of sky blue marble from the Valentine Wollastonite Mine in the Adirondacks (sample \#88-V-1; Gerdes and Valley, 1994). The metamorphic grade is upper amphibolite facies and the calcite has common inclusions of coarse flakes of graphite. 
Table 1

Major element composition of carbonate standards and certified reference glasses

\begin{tabular}{|c|c|c|c|c|c|c|c|}
\hline \multirow{2}{*}{$\begin{array}{l}\text { Oxide } \\
\text { wt.\% }\end{array}$} & \multirow{2}{*}{$\begin{array}{l}\text { KW-T6 } \\
\text { Tridacna gigas }\end{array}$} & \multirow{2}{*}{$\begin{array}{l}\text { M93-TB-FC-1 } \\
\text { Porites (sp) }\end{array}$} & \multirow{2}{*}{$\begin{array}{l}\text { PS69/318-1 } \\
\text { Desmophyllum (sp) }\end{array}$} & \multirow{2}{*}{$\begin{array}{l}\text { UWC }-1^{\text {b }} \\
\text { Marble }\end{array}$} & \multirow{2}{*}{$\begin{array}{l}\mathrm{OKA}^{\mathrm{b}} \\
\text { Carbonatite }\end{array}$} & SRM $610^{c}$ & SRM $612^{\circ}$ \\
\hline & & & & & & \multicolumn{2}{|c|}{ Synthetic reference glasses } \\
\hline$\overline{\mathrm{SiO}_{2}}$ & & $0.000(7)$ & & $0.005(11)$ & 0.000 & 69.06 & 71.79 \\
\hline $\mathrm{TiO}_{2}$ & & & & & 0.001 & 0.07 & 0.008 \\
\hline $\mathrm{Al}_{2} \mathrm{O}_{3}$ & & & & & & 1.92 & 1.99 \\
\hline $\mathrm{Fe}_{2} \mathrm{O}_{3 \text { tot }}$ & & & & & & 0.07 & 0.008 \\
\hline $\mathrm{FeO}$ & & $0.00(1)$ & & $0.00(1)$ & 0.069 & & \\
\hline $\mathrm{MnO}$ & & $0.001(8)$ & $0.00003(1)$ & $0.012(12)$ & 0.291 & 0.06 & 0.005 \\
\hline $\mathrm{MgO}$ & $0.06(3)$ & $0.221(27)$ & $3.7(18)$ & $0.090(13)$ & 0.114 & 0.08 & 0.013 \\
\hline $\mathrm{CaO}$ & $56.0(58)$ & $52.66(45)$ & $56.0(60)$ & $55.66(17)$ & 55.98 & 11.39 & 11.85 \\
\hline $\mathrm{Na}_{2} \mathrm{O}$ & & $0.607(5)$ & & $0.00(3)$ & & 13.76 & 14.02 \\
\hline $\mathrm{K}_{2} \mathrm{O}$ & & $0.009(5)$ & & $0.002(6)$ & & 0.059 & 0.008 \\
\hline $\mathrm{P}_{2} \mathrm{O}_{5}$ & & & & & & 0.078 & 0.013 \\
\hline $\mathrm{CO}_{2}$ & & $45.09(43)$ & & $44.13(16)$ & & & \\
\hline $\mathrm{SrO}$ & $0.093(3)$ & $0.927(19)$ & $0.29(1)$ & $0.046(48)$ & 1.42 & & \\
\hline $\mathrm{SO}_{3}$ & & $0.438(33)$ & & $0.012(20)$ & & & \\
\hline
\end{tabular}

The indicated uncertainties for the carbonate reference material are valid for the last digits $(1 \sigma)$.

a Element concentration is based on SIMS analyses.

b Element concentration is based on electron microprobe analyses.

c Compilation of element concentration for the matrix of the NIST Glasses (Hinton, 1999) and selected doped elements (Pearce et al., 1997).

In addition to carbonates, we also analysed the $\mathrm{B}$ isotope composition of NIST Standard Reference Materials SRMs 610 and 612; synthetic $\mathrm{Si}-\mathrm{Na}-\mathrm{Ca}-\mathrm{Al}$ oxide glasses which were produced for NIST (see Table 1 for major element compositions). The boron concentration and isotope composition of the glasses have been well characterized (e.g. Kasemann et al., 2001) and these glasses are widely distributed and commercially available.

\subsection{Sample preparation}

For (MC-ICP-MS) analyses the carbonate samples were crushed, cleaned and dissolved in 100-300 $\mu \mathrm{L}$ distilled $0.5 \mathrm{M} \mathrm{HNO}_{3}$ following the cleaning technique described in Foster (2008). Before (MC-ICP-MS) analysis, boron was separated from the dissolved carbonate samples by a one-step anion exchange procedure. The buffered sample solution ( $\mathrm{pH} \sim 5$ ) containing $30 \mathrm{ng}$ of boron was loaded on small $25 \mu \mathrm{L}$-columns filled with crushed and sieved (to $63-120 \mu \mathrm{m}$ ) boron specific Amberlite IRA 743 resin. The matrix was eluted using repeat rinses of Milli-Q water and the boron then collected using $0.5 \mathrm{HNO}_{3}$ as the eluent. The total procedural blanks typically ranged from $70-100 \mathrm{pg}$ and the column yield for this procedure is 95\% (Foster, 2008).

For TIMS analyses $10 \mathrm{mg}$ of cleaned carbonate samples (coral and bivalve) were dissolved in $1 \mathrm{M} \mathrm{HCl}$, mixed with mannitol (1 $\mathrm{mg} \mathrm{B}$ : $20 \mathrm{mg}$ mannitol), evaporated to dryness and re-dissolved in suprapure $\mathrm{H}_{2} \mathrm{O}$ for loading. The total boron blank for this procedure was less than $1 \mathrm{ng}$ (see Kasemann et al., 2005). In preparation for microanalysis, the carbonate samples and reference glasses were embedded in epoxy and polished.

\subsection{Multi-collector inductively coupled plasma-mass spectrometry}

Boron isotope analyses were carried out on a Thermo-Finnigan Neptune MC-ICP-MS at the University of Bristol following the method outlined in Foster (2008). A PFA spray chamber with a $\sim 3 \mathrm{~mL} / \mathrm{min}$ add gas of ammonia, ported in immediately after the ESI PFA $50 \mu \mathrm{L} / \mathrm{min}$ nebuliser, was used for sample introduction. This approach ensures that the spray chamber volume remains basic despite samples, standards and washes being introduced in $0.5 \mathrm{M} \mathrm{HNO}_{3}$ and a fast sample wash-out time. Solution concentrations were typically 30 $50 \mathrm{ng} \mathrm{mL}^{-1}$ boron which equates to $3-7 \mathrm{pA}$ of ${ }^{11} \mathrm{~B}$. Boron isotopes were determined by 2 min simultaneous collection of ${ }^{11} \mathrm{~B}^{+}$and ${ }^{10} \mathrm{~B}^{+}$using Faraday cups. Including blank correction and a measurement of bracketing standards, a complete measurement of a single sample takes 30 min and each sample is analysed at least twice and an average value is used. Instrumental mass bias was corrected by using the average value of bracketing, intensity-matched NIST SRM 951 boric acid reference material. The boron isotope values of the samples are given relative to NIST SRM 951 in the conventional $\delta$-notation with an uncertainty of the fully processed reference material of $0.2 \%$ ( $2 \sigma)$. For further analytical information see Foster (2008).

\subsection{Thermal ionisation mass spectrometry}

Boron isotope ratios measurements were made on a multicollector Finnigan TRITON mass spectrometer, following the method of Kasemann et al. (2001). From each sample solution, $3 \mathrm{ng}$ B together with $0.5 \mu \mathrm{L}$ B-free seawater was loaded on a Re single filament, dried at 0.7 and then heated at $1.2 \mathrm{~A}$ for $30 \mathrm{~s}$. Analyses were carried out at filament temperatures of about 1000 to $1050^{\circ} \mathrm{C}$. Boron isotopes were measured as $\mathrm{BO}^{2-}$ complexes on masses 42 and 43 . Ion beam intensities on mass 43 were typically $\sim 10 \mathrm{pA}$ and ion counting was started at intensities of about $2 \mathrm{pA}$. A complete measurement of a single sample involves 80 blocks of 12 cycles each, taking about $2 \mathrm{~h}$ of data acquisition. In each analytical session, the $n\left({ }^{11} \mathrm{~B}\right) / n\left({ }^{10} \mathrm{~B}\right)$ ratio of our certified reference material NIST SRM 951 was reproduced within $0.8 \%$ o $(2 \sigma, n=6)$. The boron isotope values are given relative to NIST SRM 951 in the conventional $\delta$-notation. Each sample solution was run in full duplicate, while two different fragments were analysed for M93-TB-FC-1, and the uncertainty of the reference material was propagated into the uncertainty on the isotope ratio of the sample $\left(2 \sigma_{\text {mean }}\right.$ or $\left.\sigma_{f}\right)$.

\subsection{Secondary ionization mass spectrometry (SIMS)}

All samples were analysed for boron concentration and isotope ratios using the single collector, secondary ionization mass spectrometer Cameca ims $4 \mathrm{f}$ at the NERC Ion Microprobe Facility at the University of Edinburgh. A primary ion beam of ${ }^{16} \mathrm{O}^{-}$and net $15 \mathrm{keV}$ with a beam current range between 10 and $40 \mathrm{nA}$ was used to produce positive secondary ions of ${ }^{10} \mathrm{~B}^{+}$and ${ }^{11} \mathrm{~B}^{+}$. The secondary ions were analysed with an energy window of $52 \mathrm{eV}$, a $150 \mu \mathrm{m}$ image field using the $450 \mu \mathrm{m}$ contrast and $1800 \mu \mathrm{m}$ field apertures. Secondary ions were counted by peak jumping on an ETP electron multiplier and the isotope ratio was measured for 200 cycles, each cycle consisting of 5 and $3 \mathrm{~s}$ integrations of ${ }^{10} \mathrm{~B}^{+}$and ${ }^{11} \mathrm{~B}^{+}$respectively. Initial measurements on samples with high boron concentration (e.g. corals, bivalves and 
Table 2

Boron concentration and isotope composition of carbonate reference materials by SIMS, MC-ICP-MS and TIMS

\begin{tabular}{|c|c|c|c|c|c|c|c|}
\hline Material & $\begin{array}{l}\left.\text { B [ } \mu \mathrm{g}^{-1}\right] \\
\text { SIMS ims-4f } \\
\pm 2 \sigma\end{array}$ & $\begin{array}{l}\text { B }\left[\mu \mathrm{g} \mathrm{g}^{-1}\right] \\
\text { LA-ICP-MS } \\
\pm 2 \sigma\end{array}$ & $\begin{array}{l}\delta^{11} \mathrm{~B}[\% \text { o }]^{\Delta M \sim 2400} \\
\text { SIMS ims-1270 } \\
\pm 1 \sigma_{\text {mean }}\end{array}$ & $\begin{array}{l}\delta^{11} \mathrm{~B}[\% \circ]^{\Delta M \sim 1600} \\
\text { SIMS ims-4f } \\
\pm 1 \sigma_{\text {mean }}\end{array}$ & $\begin{array}{l}\delta^{11} \mathrm{~B}[\% \circ]^{\Delta M \sim 500} \\
\text { SIMS } \text { ims-4f } \\
\pm 1 \sigma_{\text {mean }}\end{array}$ & $\begin{array}{l}\delta^{11} \mathrm{~B}[\% \circ] \\
\mathrm{MC}-\mathrm{ICP}-\mathrm{MS} \\
\pm 2 \sigma_{\text {mean }} \\
\end{array}$ & $\begin{array}{l}\delta^{11} \mathrm{~B}[\% \text { [ }] \\
\text { TIMS } \\
\pm 2 \sigma_{\text {mean }}\end{array}$ \\
\hline M93-TB-FC-1 & \pm 2.0 & $39.3(36)$ & \pm 0.7 & \pm 0.5 & \pm 0.7 & $24.6(1)$ & $25.0(30)$ \\
\hline UWC-1 & $12.6(6)$ & $12.9(28)$ & 7.7(19) & $7.8(12)$ & $8.8(16)$ & $7.5(2)$ & $8.6(8)$ \\
\hline PS69/318-1 & $25.4(40)$ & & & & $16.8(10)$ & $15.5(1)$ & $15.9(7)$ \\
\hline KW-T6 & 29.5(37) & & & $15.3(11)$ & $15.9(12)$ & $15.4(1)$ & \\
\hline
\end{tabular}

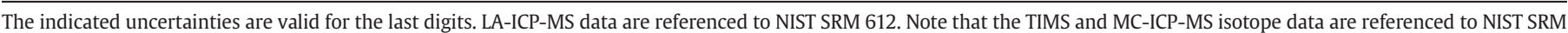
951, while the SIMS data are referenced to M93-TB-FC-1.

reference glasses; see Table 2) were performed using a mass resolution of $\sim 1600$, sufficient to resolve mass interferences of ${ }^{9} \mathrm{Be}^{1} \mathrm{H}^{+}(\Delta M=1400),{ }^{10} \mathrm{~B}^{1} \mathrm{H}^{+}(\Delta M=900)$ and ${ }^{30} \mathrm{Si}^{3+}(\Delta M=460)$. However, to increase the count rate and improve the uncertainty, analytical sessions of foraminifers were run using a mass resolution of $\sim 500$. While the molecular species ${ }^{9} \mathrm{Be}^{1} \mathrm{H}^{+}$was undetectable in the carbonate samples, the ${ }^{10} \mathrm{~B}^{1} \mathrm{H}^{+}$interference on ${ }^{11} \mathrm{~B}$ is $\sim 0.3 \%$ ond hence insignificant $(\sim 0.1 \%$ o) within the range of the analysed isotope ratios and our analytical uncertainty. Mass spectrometric results for NIST SRMs 610 and 612 under different analytical conditions are reported in Table 3.

Additional boron isotope ratio measurements were made on the Cameca ims 1270 multicollector secondary ionization mass spectrometer (SIMS) at the University of Edinburgh. Here, positive secondary ions were produced by a $5 \mathrm{nA}, 22 \mathrm{keV},{ }^{16} \mathrm{O}^{-}$primary beam focused to a $15 \mu \mathrm{m}$ spot size. The secondary ions were analysed with a mass resolution $(\Delta M)$ of $\sim 2400$ using an energy window of $50 \mathrm{eV}$, a $60 \mu \mathrm{m}$ image field, a $400 \mu \mathrm{m}$ contrast and a $3000 \mu \mathrm{m}$ field aperture. Prior to each analysis, the samples were pre-sputtered for $1 \mathrm{~min}$ to remove surface contamination. Boron isotopes were measured for 60 cycles, each cycle consisting of 5 and $3 \mathrm{~s}$ count times on ${ }^{10} \mathrm{~B}^{+}$and ${ }^{11} \mathrm{~B}^{+}$, respectively, on the single electron multiplier. Analyses of M93-TB-FC-1 showed an internal uncertainty of $1.7 \%$ ( $\left.1 \sigma_{\text {mean }}\right)$ for a single-point analysis and an external uncertainty of $2.9 \%$ o $(1 \sigma n=17)$ (see Table 4$)$.

In each analytical SIMS session the homogeneous reference glasses NIST SRM 610 and 612 were run to check the instrumental mass fractionation (IMF) and analytical uncertainty. Within a 6 day analytical session, the instrumental mass fractionation (IMF) for B was stable at the per mil level ( $1 \sigma=0.7 \%$, $n=18$ NIST SRM 610$)$. Boron isotope data are reported in the conventional $\delta^{11} \mathrm{~B} \%$ o notation relative to NIST SRM 951 (Catanzaro et al., 1970). Calibration to the reference material was through the Porites coral M93-TB-FC-1 using $\delta^{11} \mathrm{~B}_{\mathrm{M} 93}=24.8 \pm 0.4 \%$, $\left(2 \sigma_{\text {mean }}\right)$ as determined by our TIMS and MCICP-MS measurements (Table 2). The accuracy for M93-TB-FC-1 as measured by SIMS under the different analytical conditions was better than $2.9 \%$ at one standard deviation ( $1 \sigma$, see Table 4 for details).

$$
\begin{aligned}
\delta^{11} \mathrm{~B}_{\text {SIMS }}= & \left(\left(\left({ }^{11} \mathrm{~B} /{ }^{10} \mathrm{~B}_{\text {Sample }} /{ }^{11} \mathrm{~B} /{ }^{10} \mathrm{~B}_{\text {M93-TB-FC }-1}\right)_{\text {SIMS }}-1\right) * 1000\right) \\
& +\delta^{11} \mathrm{~B}_{\text {M93-TB-FC-1 }}
\end{aligned}
$$

Trace element concentrations were measured applying a $10 \mathrm{nA}$, $15 \mathrm{keV},{ }^{16} \mathrm{O}^{-}$primary beam and using the Cameca ims 4 f. Secondary ions of ${ }^{11} \mathrm{~B}(8-\mathrm{s}),{ }^{26} \mathrm{Mg}(3-\mathrm{s}),{ }^{27} \mathrm{Al}(2-\mathrm{s}),{ }^{30} \mathrm{Si}(4-\mathrm{s}),{ }^{44} \mathrm{Ca}(2-\mathrm{s}),{ }^{55} \mathrm{Mn}(5-\mathrm{s})$ and ${ }^{88} \mathrm{Sr}$ (3-s) were analysed with an energy window of $40 \mathrm{eV}$, an energy offset of $75 \mathrm{eV}$, a $25 \mu \mathrm{m}$ image field using a $150 \mu \mathrm{m}$ contrast and $750 \mu \mathrm{m}$ field aperture, and counted by peak jumping on an ETP electron multiplier for 15 cycles. The element count rates were normalised to $\mathrm{Ca}$ and the relative ion yields were obtained from the internal lab carbonate standards NCC (Swart 1990; Norman Cross Calcite, supplied by A.E. Dickson, University of Cambridge) and OKA (Carbonatite Complex in the Monteregian Hills, Quebec, Canada, supplied by J. Blundy, University of Bristol: $\mathrm{Mg}=688 \mu \mathrm{g} \mathrm{g}{ }^{-1}, \mathrm{Ca}=400439 \mu \mathrm{g} \mathrm{g} \mathrm{g}^{-1}$, $\mathrm{Mn}=2250 \mu \mathrm{g} \mathrm{g}{ }^{-1}$ and $\mathrm{Sr}=11967 \mu \mathrm{g} \mathrm{g}^{-1}$; see Allison et al. (2007) and Table 1), coral M93-TB-FC-1 $\left(B=39.6 \mu \mathrm{g} \mathrm{g}^{-1}\right)$, and the reference material NIST SRM 610 (Li, Al and Si, see Pearce et al., 1997). Note that the B concentration for M93-TB-FC-1 was taken from laser ablation-inductively coupled plasma-mass spectrometer (LA-ICP-MS) analysis performed at the Australian National University using an Agilent 7500 series mass spectrometer. Laser optics, ablation cell geometry, and signal smoothing devices are described in Eggins et al. (2003). Ca was used as an internal standard and NIST SRM 612 (Pearce et al., 1997) was

Table 3

\begin{tabular}{|c|c|c|c|c|c|c|c|c|c|c|c|c|}
\hline & \multicolumn{4}{|c|}{ Cameca $1270(\Delta M) \sim 2400$} & \multicolumn{4}{|c|}{ Cameca 4f $(\Delta M) \sim 1600$} & \multicolumn{4}{|c|}{ Cameca 4f $(\Delta M) \sim 500$} \\
\hline & \multicolumn{2}{|l|}{ SRM 610} & \multicolumn{2}{|l|}{ SRM 612} & \multicolumn{2}{|l|}{ SRM 610} & \multicolumn{2}{|l|}{ SRM 612} & \multicolumn{2}{|l|}{ SRM 610} & \multicolumn{2}{|l|}{ SRM 612} \\
\hline & $n\left({ }^{11} \mathrm{~B}\right) / n\left({ }^{10} \mathrm{~B}\right)$ & $1 \sigma_{\text {mean }}$ & $\overline{n\left({ }^{11} \mathrm{~B}\right) / n\left({ }^{10} \mathrm{~B}\right)}$ & $1 \sigma_{\text {mean }}$ & $\overline{n\left({ }^{11} \mathrm{~B}\right) / n\left({ }^{10} \mathrm{~B}\right)}$ & $1 \sigma_{\text {mean }}$ & $n\left({ }^{11} \mathrm{~B}\right) / n\left({ }^{10} \mathrm{~B}\right)$ & $1 \sigma_{\text {mean }}$ & $\overline{n\left({ }^{11} \mathrm{~B}\right) / n\left({ }^{10} \mathrm{~B}\right)}$ & $1 \sigma_{\text {mean }}$ & $n\left({ }^{11} \mathrm{~B}\right) / n\left({ }^{10} \mathrm{~B}\right)$ & $1 \sigma_{\text {mean }}$ \\
\hline & 3.886 & 0.002 & 3.879 & 0.003 & 3.899 & 0.007 & 3.880 & 0.004 & 3.893 & 0.001 & 3.885 & 0.003 \\
\hline & 3.884 & 0.002 & 3.885 & 0.003 & 3.886 & 0.002 & 3.883 & 0.004 & 3.886 & 0.001 & 3.886 & 0.003 \\
\hline & 3.898 & 0.001 & 3.875 & 0.003 & 3.888 & 0.001 & 3.889 & 0.005 & 3.887 & 0.001 & 3.880 & 0.003 \\
\hline & 3.895 & 0.002 & 3.882 & 0.003 & 3.887 & 0.003 & 3.885 & 0.005 & 3.888 & 0.001 & 3.870 & 0.003 \\
\hline & 3.892 & 0.001 & 3.881 & 0.003 & 3.892 & 0.003 & 3.883 & 0.005 & 3.885 & 0.001 & 3.879 & 0.004 \\
\hline & & & & & 3.891 & 0.004 & & & 3.885 & 0.001 & & \\
\hline & & & & & 3.894 & 0.002 & & & 3.886 & 0.001 & & \\
\hline & & & & & 3.890 & 0.002 & & & 3.884 & 0.001 & & \\
\hline & & & & & 3.892 & 0.002 & & & 3.879 & 0.001 & & \\
\hline & & & & & 3.885 & 0.002 & & & 3.882 & 0.001 & & \\
\hline Average & 3.891 & & 3.881 & & 3.891 & & 3.884 & & 3.885 & & 3.880 & \\
\hline $1 \sigma, \%$ & 1.5 & & 1.0 & & 1.1 & & 0.9 & & 1.0 & & 1.7 & \\
\hline $1 \sigma_{\text {mean }}, \%$ & 0.7 & & 0.5 & & 0.4 & & 0.5 & & 0.3 & & 0.8 & \\
\hline$\Delta_{610 / 612}$ & 0.010 & & & & 0.006 & & & & 0.005 & & & \\
\hline
\end{tabular}

Mass spectrometric results of this study for the reference material NIST SRM 610 and NIST SRM 612 determined by SIMS under different analytical conditions

Each data set represent one analytical day/session. 
Tale 4

Mass spectrometric results of this study for the coral reference material determined by SIMS under different analytical conditions

\begin{tabular}{|c|c|c|c|c|c|c|c|c|}
\hline & \multirow{2}{*}{\multicolumn{2}{|c|}{$\frac{\text { Cameca } 1270(\Delta M) \sim 2400}{\text { M93-TB-FC-1 }}$}} & \multirow{2}{*}{\multicolumn{2}{|c|}{$\frac{\text { Cameca 4f }(\Delta M) \sim 1600}{\text { M93-TB-FC-1 }}$}} & \multicolumn{4}{|c|}{ Cameca $4 \mathrm{f}(\Delta M) \sim 500$} \\
\hline & & & & & \multicolumn{2}{|l|}{ M93-TB-FC-1 } & \multicolumn{2}{|l|}{ PS69/318-1 } \\
\hline & $n\left({ }^{11} \mathrm{~B}\right) / n\left({ }^{10} \mathrm{~B}\right)$ & $1 \sigma_{\text {mean }}$ & $n\left({ }^{11} \mathrm{~B}\right) / n\left({ }^{10} \mathrm{~B}\right)$ & $1 \sigma_{\text {mean }}$ & $n\left({ }^{11} \mathrm{~B}\right) / n\left({ }^{10} \mathrm{~B}\right)$ & $1 \sigma_{\text {mean }}$ & $\overline{n\left({ }^{11} \mathrm{~B}\right) / n\left({ }^{10} \mathrm{~B}\right)}$ & $1 \sigma_{\text {mean }}$ \\
\hline & 3.795 & 0.007 & 3.762 & 0.005 & 3.793 & 0.005 & 3.744 & 0.006 \\
\hline & 3.807 & 0.005 & 3.767 & 0.005 & 3.771 & 0.005 & 3.752 & 0.006 \\
\hline & 3.796 & 0.007 & 3.792 & 0.005 & 3.776 & 0.005 & 3.769 & 0.006 \\
\hline & 3.793 & 0.006 & 3.769 & 0.005 & 3.777 & 0.005 & 3.767 & 0.006 \\
\hline & 3.805 & 0.006 & 3.774 & 0.005 & 3.761 & 0.005 & 3.764 & 0.006 \\
\hline & 3.789 & 0.007 & 3.768 & 0.004 & 3.787 & 0.005 & 3.764 & 0.007 \\
\hline & 3.802 & 0.007 & 3.773 & 0.004 & 3.791 & 0.005 & 3.757 & 0.007 \\
\hline & 3.787 & 0.005 & 3.776 & 0.004 & 3.779 & 0.005 & 3.759 & 0.005 \\
\hline & 3.784 & 0.007 & 3.772 & 0.004 & 3.778 & 0.005 & 3.731 & 0.006 \\
\hline & 3.775 & 0.007 & 3.764 & 0.003 & 3.774 & 0.005 & 3.732 & 0.006 \\
\hline & 3.764 & 0.006 & 3.766 & 0.003 & 3.780 & 0.005 & 3.739 & 0.006 \\
\hline & 3.787 & 0.007 & 3.778 & 0.003 & 3.788 & 0.005 & 3.737 & 0.006 \\
\hline & 3.779 & 0.007 & & & 3.766 & 0.005 & 3.732 & 0.007 \\
\hline & 3.792 & 0.006 & & & 3.795 & 0.005 & 3.758 & 0.007 \\
\hline & 3.788 & 0.006 & & & 3.779 & 0.005 & & \\
\hline & 3.779 & 0.006 & & & 3.799 & 0.005 & & \\
\hline & 3.793 & 0.008 & & & & & & \\
\hline Average & 3.789 & & 3.772 & & 3.781 & & 3.750 & \\
\hline $1 \sigma, \%$ & 2.9 & & 2.1 & & 2.8 & & 3.7 & \\
\hline $1 \sigma_{\text {mean }}, \%$ & 0.7 & & 0.5 & & 0.7 & & 1.0 & \\
\hline $2 \sigma_{\text {mean }}, \%$ & 1.4 & & 0.9 & & 1.4 & & 2.0 & \\
\hline
\end{tabular}

Each data set represent one analytical day/session.

used for calibration. The analytical uncertainties for element concentration determinations were less than $10 \%\left(2 \sigma_{\mathrm{r}}\right)$.

\section{Results and discussion}

\subsection{Boron isotopic composition}

Table 2 represents the boron isotope composition of the carbonate materials investigated by SIMS, TIMS and (MC-ICP-MS). All isotope data are listed in the conventional $\delta^{11} \mathrm{~B}(\%)$ notation relative to the reference material NIST SRM 951. The uncertainties of the SIMS Cameca $4 \mathrm{f}(\Delta M \sim 500)$ data are given as $\left(1 \sigma_{\text {mean }}\right)$ based on 5 analytical sessions, each involving between 3 to 6 analytical days and 63 single analyses on M93-TB-FC-1, 28 on PS69/318-1 and 9 on UWC- 1 as well as 6 analyses on KW-T6 in one analytical day. One analytical session on the Cameca ims $1270(\Delta M \sim 2400)$ included 5 analyses for UWC-1 and 14 for M93-TB-FC-1. One session on the Cameca ims $4 \mathrm{f}(\Delta M \sim 1600)$ covered 6 consecutive analyses for KW-T6 and UWC-1, and 12 for M93-TB-FC-1. The uncertainties on the TIMS and (MC-ICP-MS) data are given as $2 \sigma$ based on at least two analyses of the same sample solution. Also provided in Table 2 are the boron concentration data for the carbonate samples.

\subsection{Bulk analytical techniques}

The boron isotope data obtained by TIMS and (MC-ICP-MS) on the carbonate material agree to within $1.1 \%$ (Table 2, Fig. 1a). This is quite an encouraging result given the different factors that govern uncertainties in these two different methods. While (MC-ICP-MS) involves column chemistry to separate B from the matrix and corrects for instrumental bias by rapid sample standard bracketing, TIMS has to face slightly different matrices and can control instrumental mass bias only by meticulous loading and running protocols. Clearly, the level of agreement (which is close to analytical uncertainty) suggests that there are no systematic biases between the two approaches.

\subsection{Microanalytical techniques}

The bulk samples and SIMS data on the carbonate materials agree to within $1.3 \%$, independent on the boron concentration or carbonate matrix (Table 2, Fig. 1a). To check the isotopic homogeneity of all carbonate samples, SIMS profiles have been performed on either different sample fragments or along growth axis. For the inorganic calcite UWC-1 within and between crystal heterogeneities of $~ 3.2 \%$ 。 $(1 \sigma)$ have been found. Ion profiles across the biogenic samples demonstrate isotopic variations $(1 \sigma)$ of $2.9 \%$ o $(n=17)$ for M93-TB-FC-1, $3.2 \%$ o $(n=10)$ for KW-T6 and 3.7\% $(n=14)$ for PS69/318-1.

To investigate possible analytical effects on the $\mathrm{B}$ isotope data produced by SIMS using a low mass resolution of $\Delta M \sim 500$, additional isotope ratio measurements on high $\mathrm{B}$ concentrated samples were made on the Cameca ims 1270 and ims $4 \mathrm{f}$ using a mass resolution of $\Delta M \sim 2400$ and 1600, respectively. Good agreement between the data $(<1.0 \%$, Table 2$)$ supports the reliability of the data sets.

The trace element concentration in carbonates, such as iron, magnesium and strontium, can vary significantly (Table 1 ) potentially influencing the relative ion yield of the analysed elements and imposing a potential matrix dependent IMF on the isotope measurements ( $R$. Hinton pers. comm. 2008) as already documented for silicates (e.g. Steele et al., 1981). While the Sr amount content is quite variable in corals (e.g. Allison et al., 2001), it is rather constant and homogeneous in foraminifera (see Schmidt et al., 2008 for discussion). In contrast, the $\mathrm{Mg}$ amount content in foraminiferal calcite tests can vary not only between different species but also between different chambers and calcite layers in individual foraminifers (e.g. Eggins et al., 2004; Schmidt et al., 2008). Hence, the influence of $\mathrm{Mg}$ and $\mathrm{Sr}$ on the IMF has to be assessed. The carbonate reference material used in this study have different $\mathrm{MgO}$ and $\mathrm{SrO}$ amount contents ranging from $0.06 \%$ to $3.7 \%$ and $0.05 \%$ to $1.4 \%$, respectively and cover the overall compositional range for most corals and foraminifers (e.g. Allison et al., 2001; Schmidt et al., 2008). In addition the calcium carbonate reference material includes the polymorphs aragonite (e.g. T. gigas, Porites) and calcite (e.g. Desmophyllum), which allows us to check the influence of the crystal structure on the IMF. For the four carbonate reference materials (M93TB-FC-1, PS69/318-1, UWC-1, KW-T6), we obtained the same IMF within each analytical session. This suggests that within the compositional range of the analysed material neither the $\mathrm{Mg}$ and $\mathrm{Sr}$ amount content nor the crystal structure affect the IMF. This confirms that the B isotope data obtained for the reference carbonates by SIMS are sufficiently accurate and demonstrate that the ion microprobe technique can be used for the in situ analyses of boron isotopic variations in carbonates of 
a

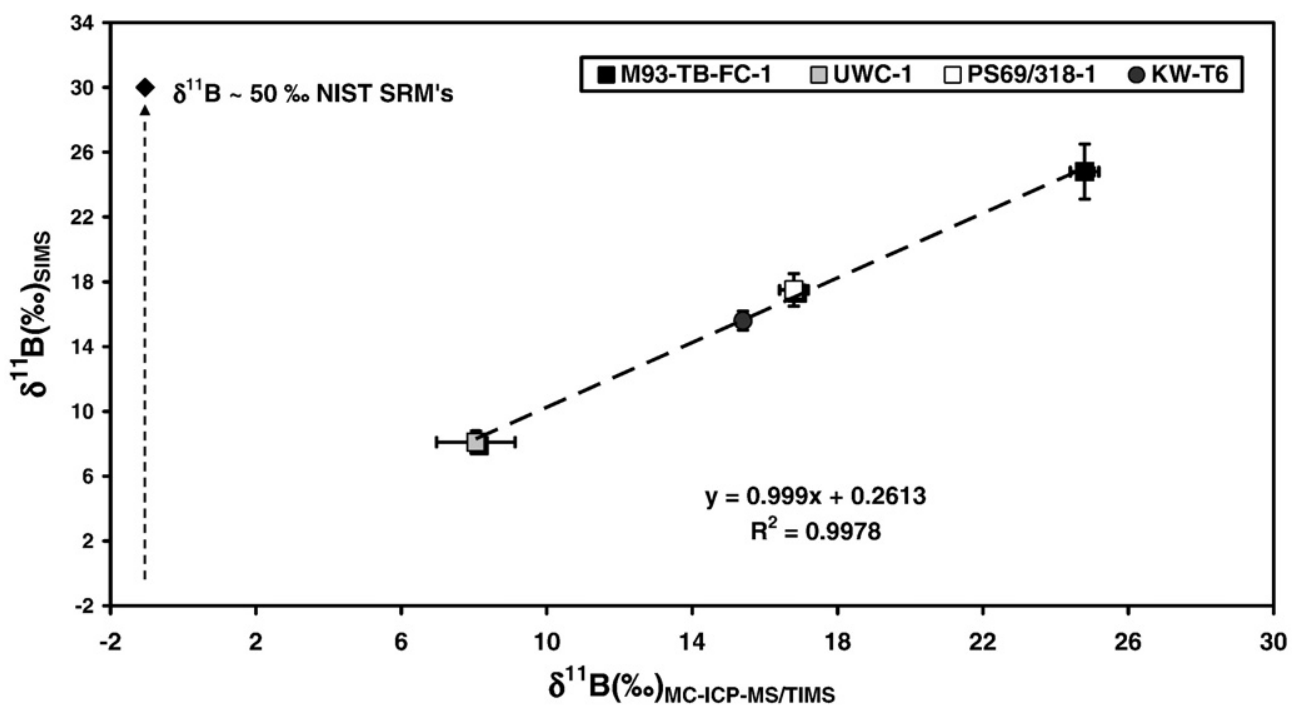

b

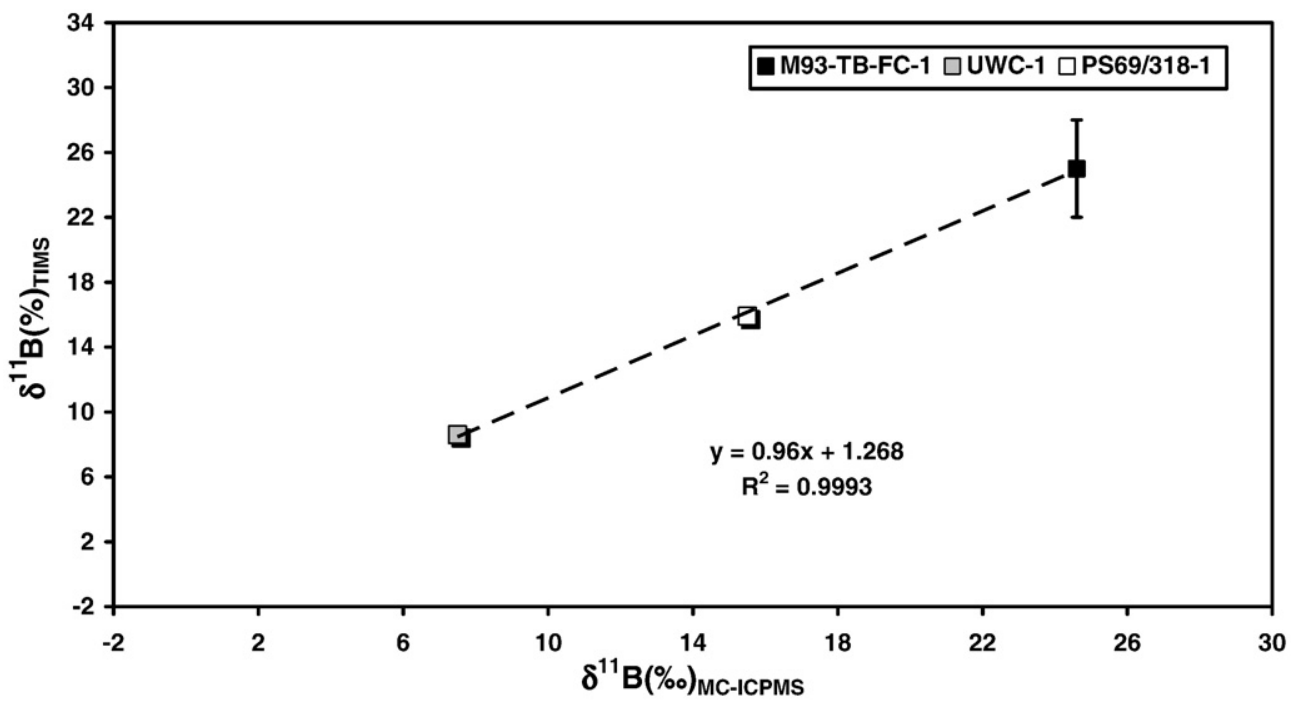

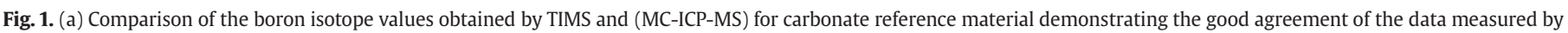

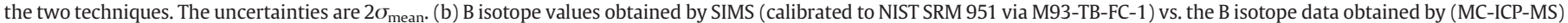

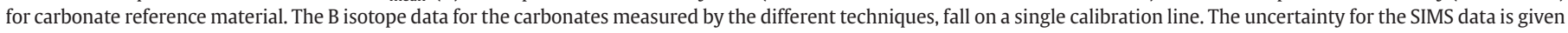
as $1 \sigma_{\text {mean }}$.

similar composition. To increase the range in sample matrices and to check if the carbonate reference material can also be used as reference for samples with matrices far beyond such non-silicates, we examined the silicate glass reference materials from NIST that have matrices with high Si-Na-Ca-Al-element concentrations.

SIMS profiles across the NIST SRM glass wafers demonstrate an overall boron isotope homogeneity to better than $0.8 \%$ o $\left(1 \sigma_{\text {mean }}\right)$ (see Table 3). However, the SIMS B isotope data of the two NIST glasses are considerable different (off by 50\%) from the published values (Kasemann et al., 2001) when calibrated relative to M93-TB-FC-1 (see Fig. 1). This demonstrates a considerable matrix effect on the boron isotope composition and excludes the NIST reference material with its silicate framework and unusual element composition as a reference material for carbonate. However, given the good isotopic homogeneity of the NIST glasses compared to the carbonates materials (see chapter 2.5.), each analytical session combined carbonate and silicate reference analyses to monitor instrumental stability, mass fractionation and analytical uncertainty.

\subsection{Microanalysis of foraminiferal tests: $\mathrm{pH}$ and vital effect}

The ultimate application for in situ boron isotope analysis using SIMS is on foraminiferal tests, since the constraint on the applicability of foraminifers as an archive for environmental information is the heterogeneity on the internal and inter-individual scale rather than the analytical precision (Boyle, 1988). These heterogeneities can result from the calcification process itself or from differences in the carbonate chemistry at the site of calcification induced by symbiont photosynthesis or host/symbiont respiration. In addition, differences in depth habitat, seasonality, changes in the microhabitat, bioturbation as well as post-depositional alteration can add inter- as well as intra-individual heterogeneity. To avoid these problems we analysed 
Table 5

Summary of analytical results of cultured 0 . universa and chemical composition of seawater used for culture experiments

\begin{tabular}{|c|c|c|c|c|c|c|c|c|c|c|c|c|}
\hline Sample & $\mathrm{pH}$ & $\mathrm{B}\left[\mu \mathrm{g} \mathrm{g}^{-1}\right]$ & $\begin{array}{l}\text { Total } \\
\text { Alkalinity } \\
\mu e q \mathrm{~kg}^{-1}\end{array}$ & $\begin{array}{l}\mathrm{CO}_{3}^{2-} \\
\mu \mathrm{mol} \mathrm{kg}^{-1}\end{array}$ & $\begin{array}{l}\text { Seawater } \\
\delta^{11} \mathrm{~B}[\% \circ] \\
\pm 1 \sigma_{\text {mean }}\end{array}$ & $\begin{array}{l}\text { Foraminifera } \\
\delta^{11} \mathrm{~B}[\% \text { \% } \\
\pm 1 \sigma_{\text {mean }}\end{array}$ & $\begin{array}{l}\mathrm{pH} \text { Calculated } \\
{ }^{11-10} K_{\mathrm{B}}=1.0194 \\
\pm 1 \sigma_{\text {mean }}\end{array}$ & $\begin{array}{l}\mathrm{pH} \text { Calculated } \\
{ }^{11-10} K_{\mathrm{B}}=1.0272 \\
\pm 1 \sigma_{\text {mean }}\end{array}$ & $\underset{ }{{ }^{11-10}{ }^{\mathrm{pH}} K_{\mathrm{B}}=1.0194}$ & $\underset{{ }^{11-10}}{\Delta \mathrm{pH}} K_{\mathrm{B}}=1.0272$ & $\begin{array}{l}\text { Vital effect } \\
{ }^{11-10} K_{\mathrm{B}}=1.0194\end{array}$ & $\begin{array}{l}\text { Vital effect } \\
{ }^{11-10} K_{\mathrm{B}}=1.0272\end{array}$ \\
\hline BS 10 & 8.19 & 50.8 & 3333 & 232 & $-6.9(6)$ & $-22.9(7)$ & $7.99(12)$ & $8.44(5)$ & -0.23 & -0.26 & 1.9 & -3.6 \\
\hline BS 23 & 8.67 & 50.4 & 4769 & 571 & $-6.3(5)$ & $-17.1(10)$ & $8.52(10)$ & $8.78(7)$ & -0.16 & -0.11 & 1.8 & -1.7 \\
\hline
\end{tabular}

The indicated uncertainties are valid for the last digits.

SIMS boron isotope data are given relative to NIST SRM 951 and are referenced to M93-TB-FC-1.

samples of 0 . universa whose ultimate chambers were completely build in a controlled culture medium (Sanyal et al., 1995, 2001).

We applied the in situ B isotope measurement technique developed on our carbonate reference material and described above on 2 specimens of 0 . universa. The planktic foraminifers were collected by scuba divers and maintained in culture analogous to published experiments of Globigerinoides sacculifer by Sanyal et al. (2001). The aim of the cultures was to establish an empirical relationship between $\mathrm{pH}$ and the boron isotope compositions. The principal seawater chemistry is given in Table 5 while the details of the experiment i.e. collection and culturing are described in Sanyal et al. (2001). Essentially, the seawater was artificially enriched to 10 times boron with a known $\delta^{11} \mathrm{~B}$ and the $\mathrm{pH}$ was adjusted to a target value of ca. 7.6, 8.2 or 8.6. The final culture water $\delta^{11} \mathrm{~B}$ and $\mathrm{pH}$ for the two experiments BS10 and BS23 were $-6.9 \pm 0.6 \%$ and $8.19 \pm 0.05$ and $-6.3 \pm 0.5 \%$ and $8.67 \pm 0.05$, respectively. The boron isotope composition of the two specimens from experiment BS10 and BS23 is $-22.9 \pm 0.7 \%$ ( $1 \sigma_{\text {mean }}$, $n=7)$ and $-17.1 \pm 1.0 \%$ 。 $\left(1 \sigma_{\text {mean }}, n=6\right)$, respectively (Table 5$)$ and based on multiple single spot analysis along the spherical chamber. Specimens maintained at lower $\mathrm{pH}$ as well as those cultured at seawater boron concentration, produced thin spherical chambers that did not allow for sufficient $\delta^{11} \mathrm{~B}$ analyses to be included in the isotope compilation.
To compare the measured $\delta^{11} \mathrm{~B}$ values with the given $\mathrm{pH}$ conditions of the modified seawater, the foraminiferal $\delta^{11} \mathrm{~B}$ values were converted to $\mathrm{pH}$ by

$$
\begin{aligned}
\mathrm{pH}= & \mathrm{p} K_{\mathrm{B}}-\log \left(\left(\delta^{11} \mathrm{~B}_{\text {seawater }}-\delta^{11} \mathrm{~B}_{\text {sample }}-a\right) /\left(\delta^{11} \mathrm{~B}_{\text {seawater }}{ }^{-11-10} K_{\mathrm{B} .} *\right.\right. \\
& \left.\left.\left(\delta^{11} \mathrm{~B}_{\text {sample }}+a\right)-1000 *\left({ }^{11-10} K_{\mathrm{B} .}-1\right)\right)\right)
\end{aligned}
$$

where the equilibrium constant $\mathrm{p} K_{\mathrm{B}}$ is 8.574 for the experimental temperature of $27{ }^{\circ} \mathrm{C}$ (Lewis and Wallace, 1998), $a$ is the species specific vital effect and ${ }^{11-10} K_{\mathrm{B}}$ the boron isotope equilibrium constant of either $1.0272 \pm 0.0006$ (Klochko et al., 2006) or 1.0194 (Kakihana et al., 1977). Note that this equation is an approximation and accurately applicable only in natural seawater conditions. The use of $\delta^{11} \mathrm{~B}$ values distinctive to normal marine values e.g. negative $\delta^{11} \mathrm{~B}$ values can result in inaccurate $\mathrm{pH}$ calculations. Hence, we converted our $\delta^{11} \mathrm{~B}$ data relative to modern seawater values prior to their translation into $\mathrm{pH}$ values.

Until recently, most $\delta^{11} \mathrm{~B}$-based $\mathrm{pH}$ reconstructions applied the theoretical ${ }^{11-10} K_{\mathrm{B}}=1.0194\left(25{ }^{\circ} \mathrm{C}\right)$ of Kakihana et al. (1977), yet foraminiferal culture experiments and diffusion-reaction models calculating the micro-environmental $\mathrm{pH}$ of the foraminifer suggested that the calculated value of the thermodynamic fractionation must

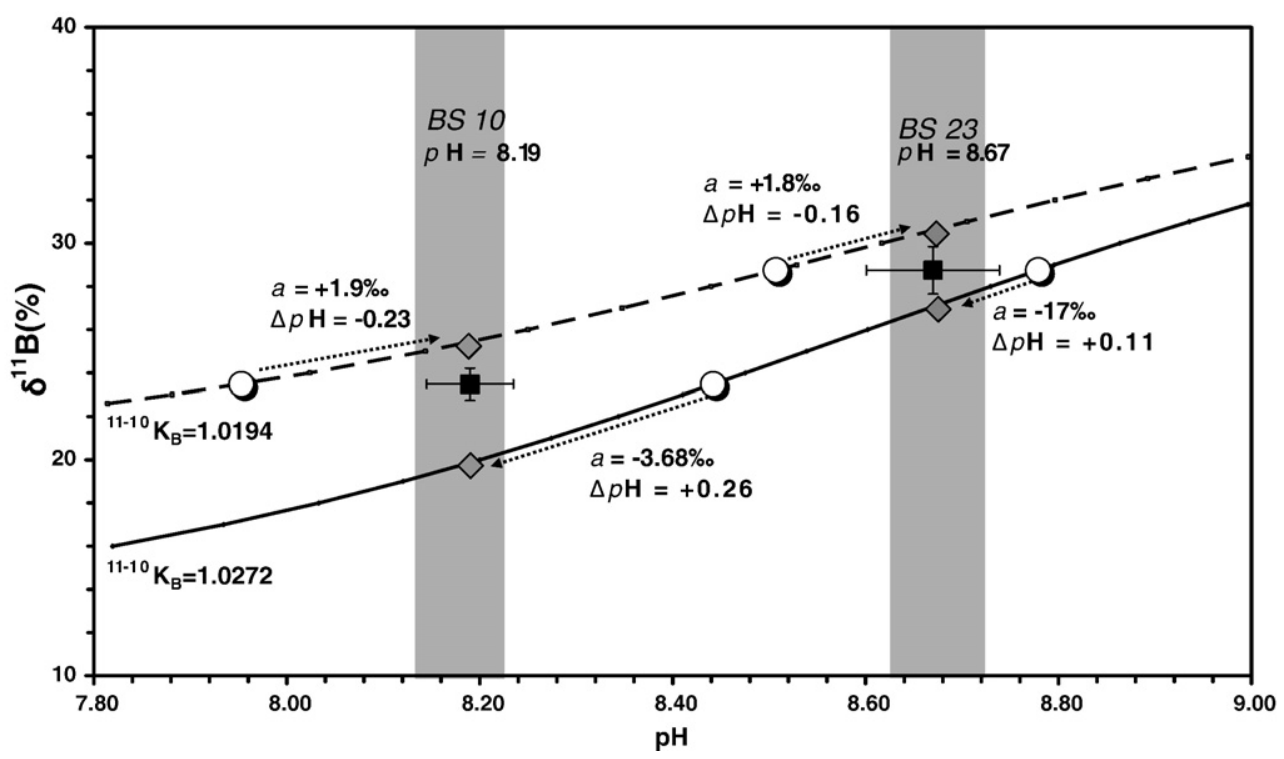

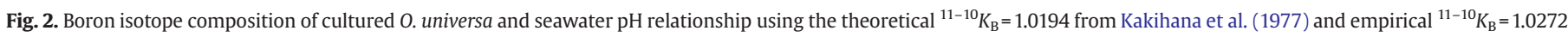

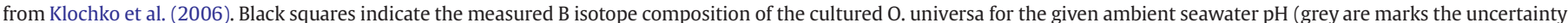

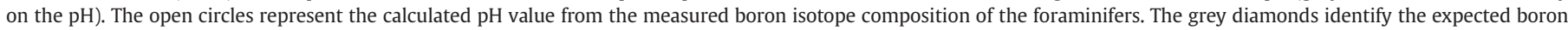

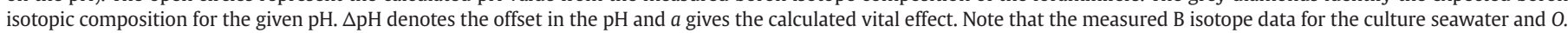
universa are converted relative to modern seawater $\left(\delta^{11} \mathrm{~B}_{\text {Seawater }}\right.$ is taken to be $39.5 \%$ ) to allow for accurate pH calculations (see text). 
have been larger than $20 \%$ (Zeebe et al., 2003). In a recent evaluation of the $\delta^{11} \mathrm{~B}-\mathrm{pH}$ proxy, Pagani et al. (2005) estimated a ${ }^{11-10} K_{\mathrm{B}}$ from inorganic carbonate precipitation experiments (Sanyal et al., 2000) of $1.0267\left(22^{\circ} \mathrm{C}\right)$. This higher value has since then been supported in an experimental study of B-isotope fractionation in seawater by Klochko et al. (2006), presenting an empirical ${ }^{11-10} K_{\mathrm{B}}$ of $1.0272 \pm 0.0006$ $\left(2 \sigma_{\text {mean }} ; 25{ }^{\circ} \mathrm{C}\right)$. Here, we discuss our B isotope data using both the recently published (Klochko et al., 2006) as well as the traditionally in palaeo-reconstructions used fractionation factor (Kakihana et al., 1977).

In a direct $\delta^{11} \mathrm{~B}$ to $\mathrm{pH}$ conversion, 0 . universa (BS10) cultured at $\mathrm{pH}$ 8.19 has a $\delta^{11} \mathrm{~B}$ value of $-22.9 \%$ 。 resulting in a $\mathrm{pH}$ of $8.44 \pm 0.5$ using ${ }^{11-10} K_{\mathrm{B}}=1.0272$ and a $\mathrm{pH}$ of $7.99 \pm 0.12$ while using ${ }^{11-10} K_{\mathrm{B}}=1.0194$. Similarly, at $\mathrm{pH} 8.67$ (BS23) the cultured O. universa has a $\delta^{11} \mathrm{~B}$ of $-17.1 \%$ o which implies a pH of $8.78 \pm 0.7$ using ${ }^{11-10} K_{\mathrm{B}}=1.0272$ and $8.52 \pm 0.1$ using ${ }^{11-10} K_{\mathrm{B}}=1.0194$ (Fig. 2, Table 5). Hence, by applying the $\delta^{11} \mathrm{~B}_{\text {Borate }}-\mathrm{pH}$ relationship of Kakihana et al. (1977) to our $\delta^{11} \mathrm{~B}$ results on 0 . universa, the recorded $\mathrm{pH}$ values are 0.16 (BS23) and 0.23 (BS10) $\mathrm{pH}$ units lower than the artificial seawater. This translates to lower $\delta^{11} \mathrm{~B}$ values of 1.8 respectively $1.9 \%$. The general negative offset between the given and calculated $\mathrm{pH}$ values using the fractionation factor from Kakihana et al. (1977) is consistent with results fromSanyal et al. (1996) and Zeebe et al. (2003). In contrast, applying the theoretical $\delta^{11} \mathrm{~B}-\mathrm{pH}$ curve of Klochko et al. (2006), there is an offset to higher $\mathrm{pH}$ values of 1.1 to 2.6 units, respectively $\delta^{11} \mathrm{~B}$ of 1.7 and $3.6 \%$. Consequently, this results in contrasting "vital effects" of $a \approx+1.9$ for ${ }^{11-10} K_{\mathrm{B}}=1.0194$ and $a \approx-2.6$ for ${ }^{11-10} K_{\mathrm{B}}=1.0272$ (see Fig. 2 and Table 5).

While the boron isotope composition of foraminifers has been established as an empirical palaeo-pH proxy (e.g. Spivack et al., 1993; Sanyal et al., 1995; Palmer et al., 1998; Pearson and Palmer, 2000; Hönisch and Hemming, 2004; Zeebe et al., 2008) it was questioned whether foraminifers record the $\mathrm{pH}$ of the seawater or the $\mathrm{pH}$ of the microenvironment (see Zeebe et al., 2003 for discussion). Vital effects such as symbiont activity, respiration and calcification alter the $\mathrm{pH}$ of the ambient water in which the foraminifer lives, forming a microenvironment with different $\mathrm{pH}$ around the test (Jørgensen et al., 1985; Rink et al., 1998; Wolf-Gladrow et al., 1999; Zeebe et al., 2003). Respiration, i.e. production of $\mathrm{CO}_{2}$, results in lower $\mathrm{pH}$, while photosynthesis, i.e. consumption of $\mathrm{CO}_{2}$ and/or $\mathrm{HCO}_{3}^{-}$creates more alkaline conditions. In case of 0 . universa, $\mathrm{pH}$ microsensor studies (Rink et al., 1998) as well as modelled pH profiles (Wolf-Gladrow et al., 1999) of the foraminiferal microenvironment demonstrated that the $\mathrm{pH}$ at the shell surface dropped about $0.4 \mathrm{pH}$ units in darkness, i.e. without photosymbiotic activity and solely with respiration, and increased between 0.25 and up to $0.5 \mathrm{pH}$ units above ambient seawater during symbiont photosynthesis. Assuming a ratio of dark: light calcification in 0 . universa about 1:3 (Lea et al., 1995), the $\mathrm{pH}$ of the microenvironment should be between 0.1 and $0.37 \mathrm{pH}$ units higher than the seawater. An experimental study byZeebe et al. (2001) also predicted that the $\delta^{11} \mathrm{~B}$ of 0 . universa should be about $1.6 \%$ 。 (Zeebe et al., 2003) and up to 3.7\% higher than the $\delta^{11} \mathrm{~B}$ of inorganic calcite depending on the assumed $\mathrm{pH}$ profile and photosynthetic rate (Rink et al., 1998, Wolf-Gladrow et al., 1999), as well as the applied fractionation factor. In comparisons, the average $\delta^{11} \mathrm{~B}$ of the calcite test from G. sacculifer should be $\sim 3.2 \%$ o heavier than the $\delta^{11} \mathrm{~B}$ of the bulk seawater (Zeebe et al., 2003).

In addition, Zeebe et al. (2003) also calculated the effect of the 10fold boron enrichment to result in smaller $\mathrm{pH}$ differences and hence in smaller $\delta^{11} \mathrm{~B}$ offsets in the foraminiferal carbonate compared to specimens grown in normal seawater due to the buffer capacity of the boric acid/borate buffer. Hence, regardless of the chosen $\mathrm{pH}$ profile and chemical composition of the seawater, the $\mathrm{pH}$ recorded in the calcite test should be always above bulk seawater. Consequently, the relative offset towards lower $\mathrm{pH}$ values $(\sim 0.2 \mathrm{pH}$ units $)$ and the positive vital effect $(\sim 1.9)$ using the theoretical thermodynamic fractionation factor by Kakihana et al. (1977) are significantly lower than could be explained by any biological process. This paradox and the challenge it is posing on the traditionally in palaeo-reconstructions used fractionation factor has already been described by Zeebe et al. (2003). In contrast, the positive $\mathrm{pH}(\sim 0.19 \mathrm{pH}$ units) and negative vital ( - 1.9) offset using the fractionation factor by Klochko et al. (2006) fits the theoretical calculations including the ecological considerations very well. A similar observation has been made by Foster (2008) on a core top calibration of planktic and benthic foraminiferal species. By using the $\delta^{11} \mathrm{~B}_{\text {Borate }}-\mathrm{pH}$ relationship of Klochko et al. (2006), the study revealed a strong agreement between the measured boron isotopic composition of the foraminifers, the $\delta^{11} \mathrm{~B}_{\text {Borate }}$ of the seawater and the vital effect. However, it should be noted that the empirical calibrations that have been produced to date using the theoretical thermodynamic fractionation factor by Kakihana et al. (1977), remain equally valid as long as they are applied to $\mathrm{pH}$ calculations restricted to small overall variations and $\mathrm{pH}$ values similar those of the modern ocean.

\section{Conclusions}

We determined boron concentrations and isotope data for a suite of biogenic and inorganic carbonates, which are currently distributed between several laboratories to increase the amount of B isotope analysis and to provide a new set of microanalytical and bulk analytical calibration materials. We also measured boron isotope ratio for the NIST standard reference materials SRM 610 and SRM 612. These glasses are commonly used as microanalytical calibration and reference materials for various in situ methods. The B isotope data for all carbonates samples determined by MC-ICP-MS and TIMS agree within analytical uncertainty. This is reassuring given the very different controlling parameters of the two techniques. The bulk analytical and SIMS data agree to within $1.3 \%$, independent of the boron concentration and carbonate matrix. The limiting factor on the uncertainty is generally the internal heterogeneity of the carbonate samples rather than the analytical precision. This confirms that the $\mathrm{B}$ isotope data on the carbonate samples, obtained by SIMS, are sufficiently accurate to be used for geochemical applications. It also demonstrates that this technique is a useful tool for the in situ analysis of $B$ isotope ratios in carbonate materials to distinguish between the biological and environmental control on the $\mathrm{B}$ isotope composition in biogenic carbonates and to improve our current understanding of biological influences on the boron isotope fractionation. In addition, the high-spatial resolution capacity would allow analysing the $\mathrm{B}$ isotope composition of carbonate material e.g. single foraminifers or partially dissolved and recrystallised material from past ocean acidification events previously inaccessible using bulk analytical techniques. The good agreement between the $\delta^{11} \mathrm{~B}_{\text {Borate }}$ of the seawater and the proposed vital effect of 0 . universa and other planktic and benthic foraminiferal species clearly favours and supports the application of the recent experimental determination of ${ }^{11-10} K_{\mathrm{B}}=1.0272$ in future studies of boron isotopes as a pH proxy.

\section{Acknowledgements}

We thank Claus-Dieter Hillenbrand (British Antarctic Survey, Cambridge) and Gerd Kuhn (Alfred Wegener Institute for Polar and Marine Research, Bremerhaven), for providing the Cold water coral Desmophyllum (sp) PS69/318-1. We are grateful to John Valley (University of Wisconsin) for providing sample UWC-1, Kevin Welsh and Mary Elliot (UoE) for KW-T6, and Alexander Tudhope (UoE) for coral M93-TB-FC-1. We thank Carolyn Taylor (UoB) and Michael Hall (UoE) for the sample preparation, John Craven and Richard Hinton (UoE) for support with the Cameca ims 1270 and David Steele for the electron microprobe data. Moreover, we would like to thank Hugh O'Neill for his generous support during SAK's stay at the Australian National University. This work benefited from valuable discussions 
with R. Hinton (UoE). DNS would like to thank the Royal Society for financial support via a URF. JB would like to thank the PTJ and the BMBF for their support (03F0450A). Part of this work was supported by a NERC Scientific Services Grant (Ion Microprobe Facility) awarded to DNS (IMF288/1006). The manuscript has benefited from careful reviews by two anonymous reviewer and editorial handling from D. Rickard.

\section{References}

Allison, N., Finch, A.A., Sutton, S.R., Newville, M., 2001. Strontium heterogeneity and speciation in coral aragonite: implications for the strontium paleothermometer. Geochimica et Cosmochimica Acta 65, 2669-2676.

Allison, N., Finch, A.A., Webster, J.M., Clague, D.A., 2007. Palaeoenvironmental records from fossil corals: the effects of submarine diagenesis on temperature and climate estimates. Geochimica et Cosmochimica Acta 71, 4693-4703.

Bé, A.W.H., 1980. Gametogenic calcification in a spinose planktonic foraminifer, Globigerinoides sacculifer (Brady). Marine Micropaleontology 5, 283-310.

Blamart, D.D., Rollion-Bard, C., Meibom, A., Cuif, J.-P., Juillet-Leclerc, A., Dauphinet, Y., 2007. Correlation of boron isotopic composition with ultra-structure in the deep-sea coral Lophelia pertusa: implications for biomineralization and paleo-pH. Geochemistry Geophysics Geosystems 8, Q12001.

Boyle, E., 1988. Cadmium: chemical tracer of deepwater paleoceanography. Paleoceanography 3, 471-489.

Catanzaro, E.J., Champion, C.E., Garner, E.L., Marinenko, G., Sappenfield, K.M., Shields, W.R., 1970. Boric Assay; Isotopic, and Assay Standard Reference Materials. Special Publication, vol. 260 (17). US National Bureau of Standards. 70 pp.

DeConto, R.M., Pollard, D., 2003. Rapid Cenozoic glaciation of Antarctica induced by declining atmospheric $\mathrm{CO}_{2}$. Nature 421, 245-249.

Eggins, S., De Deckker, P., Marshall, J., 2003. Mg/Ca variation in planktonic foraminifera tests: implications for reconstructing palaeo-seawater temperature and habitat migration. Earth and Planetary Science Letters 212, 291-306.

Eggins, S.M., Sadekov, A., De Deckker, P., 2004. Modulation and daily banding of $\mathrm{Mg} / \mathrm{Ca}$ in Orbulina universa tests by symbiont photosynthesis and respiration: a complication for seawater thermometry? Earth and Planetary Science Letters 225, 411-419.

Foster, G.L., 2008. Seawater $\mathrm{pH}, \mathrm{pCO}>2$ and $\left[\mathrm{CO}_{3}^{2-}\right]$ variations in the Caribbean Sea over the last 130 kyr: a boron isotope and B/Ca study of planktic foraminifera. Earth and Planetary Science Letters 271, 254-266.

Foster, G.L., Ni, Y., Haley, B., Elliott, T., 2006. Accurate and precise isotopic measurement of sub-nanogram sized samples of foraminiferal hosted boron by total evaporation NTIMS. Chemical Geology 230, 161-174.

Gerdes, M.L., Valley, J.W., 1994. Fluid flow and mass transport at the Valentine wollastonite deposit, Adirondack Mountains, N.Y. Journal of Metamorphic Geology 12, 589-608.

Gonfiantini, R., Tonarini, S., Gröning, M., Adorni-Braccesi, A., Al-Ammar, A.S., Astner, M., Bächler, S., Barnes, R.M., Bassett, R.L., Cocherie, A., Deyhle, A., Dini, A., Ferrara, G. Gaillardet, J., Grimm, J., Guerrot, C., Krähenbühl, U., Layne, G., Lemarchand, D., Meixner, A., Northington, D.J., Pennisi, M., Reitznerová, E., Rodushkin, I., Sugiura, N., Surberg, R., Tonn, S., Wiedenbeck, M., Wunderli, S., Xiao, Y., Zack, T., 2003. Intercomparison of boron isotope and concentration measurements. Part 2: evaluation of results. Geostandards Newsletter: The Journal of Geostandards and Geoanalysis 27, 41-57.

Graham, C.M., Valley, J.W., Eiler, J.M., Wada, H., 1998. Timescales and mechanisms of fluid infiltration in a marble: an ion microprobe study. Contributions to Mineralogy and Petrology 132, 371-389.

Hamilton, C.P., Spero, H.J., Bijma, J., Lea, D.W., 2008. Geochemical investigation of gametogenic calcite addition in the planktonic foraminifera Orbulina universa. Marine Micropaleontology 68, 256-267.

Hemleben, C., Spindler, M., Anderson, O.R., 1989. Modern Planktonic Foraminifera. Springer, New York. 363 pp.

Hemming, N.G., Hanson, G.N., 1992. Boron isotopic composition and concentration in modern marine carbonates. Geochimica et Cosmochimica Acta 56, 537-543.

Hinton, R.W., 1999. NIST SRM 610, 611 and SRM 612, 613 multi-element glasses: constraints from element abundance ratios measured by microprobe techniques. Geostandards Newsletter: The Journal of Geostandards and Geoanalysis 23, 197-207.

Hönisch, B., Hemming, G.N., 2004. Ground-truthing the boron isotope-paleo-pH proxy in planktonic foraminifera shells: partial dissolution and shell size effects. Paleoceanography 19. doi:10.1029/2004PA001026.

Hönisch, B., Hemming, N.G., Grottoli, A.G., Amat, A., Hanson, G.N., Bijma, J., 2004 Assessing scleractinian corals as recorders for paleo-pH: empirical calibration and vital effects. Geochimica et Cosmochimica Acta 68, 3675-3685.

Hönisch, B., Hemming, N.G., Loose, B., 2007. Comment on "A critical evaluation of the boron isotope-pH proxy: The accuracy of ancient ocean $\mathrm{pH}$ estimates" by Pagani, M., Lemarchand, D., Spivack, A., Gaillardet, L. Geochimica et Cosmochimica Acta 71 (6), 1636-1641.

Ishikawa, T., Nakamura, E., 1993. Boron isotope systematics of marine-sediments. Earth and Planetary Science Letters 117 (3-4), 567-580.

Jørgensen, B.B., Erez, J., Revsbech, N.P., Cohen, Y., 1985. Symbiotic photosynthesis in a planktonic foraminifera, Globigerinoides sacculifer (Brady), studied with microelectrodes. Limnology and Oceanography 30, 1253-1267.

Kakihana, H., Kotake, M., Satoh, S., Nomura, M., Okamoto, M., 1977. Fundamental studies on the ion-exchange separation of boron isotopes. Bulletin of the Chemical Society of Japan 50, 158-163.

Kasemann, S., Meixner, A., Rocholl, A., Vennemann, T., Rosner, M., Schmitt, A.K., Wiedenbeck, M., 2001. Boron and oxygen isotope composition of certified reference materials NIST SRM 610/612 and reference materials JB-2 and JR-2. Geostandards Newsletter: The Journal of Geostandards and Geoanalysis 25 (2-3), 405-416.

Kasemann, S.A., Hawkesworth, C.J., Prave, A.R., Fallick, A.E., Pearson, P.N., 2005. Boron and calcium isotope composition in Neoproterozoic carbonate rocks from Namibia: evidence for extreme environmental change. Earth and Planetary Science Letters 231, 73-86.

Kasemann, S.A., Schmidt, D.N., Pearson, P.N., Hawkesworth, C.J., 2008. Biological and ecological insights into $\mathrm{Ca}$ isotopes in planktic foraminifers as a palaeotemperature proxy. Earth and Planetary Science Letters 271 (1-4), 292-302.

Klochko, K., Kaufman, A.J., Yao, W., Byrne, R.H., Tossell, J.A., 2006. Experimental measurement of boron isotope fractionation in seawater. Earth and Planetary Science Letters 248 (1-2), 276-285.

Lea, D.W., Martin, P.A., Chan, D.A., Spero, H.J., 1995. Calcium uptake and calcification rate in the planktonic foraminifer Orbulina universa. Journal of Foraminiferal Research 25, 14-23.

Lewis, E., Wallace, D.W.R., 1998. Program developed for $\mathrm{CO}_{2}$ system calculations. ORNL/ CDIAC-105 Carbon Dioxide Information Analysis Center, Oak Ridge National Laboratory. U.S. Department of Energy, Oak Ridge, Tennessee.

Ni, Y., Foster, G.L., Bailey, T., Elliott, T., Schmidt, D.N., Pearson, P., Haley, B., Coath, C., 2007. A core top assessment of proxies for the ocean carbonate system in surface dwelling foraminifers. Paleoceanography 22 (3), PA3212 http://dx.doi.org/10.1029/ 2006 PA001337.

Nürnberg, D., Bijma, J., Hemleben, C., 1996. Assessing the reliability of magnesium in foraminiferal calcite as a proxy for water mass temperatures. Geochimica Cosmochimica Acta 60, 803-814.

Pagani, M., Lemarchand, D., Spivack, A., Gaillardet, J., 2005. A critical evaluation of the boron isotope-pH proxy: the accuracy of ancient ocean $\mathrm{pH}$ estimates. Geochimica et Cosmochimica Acta 69 (4), 953-961.

Palmer, M.R., Pearson, P.N., 2003. A 23,000-year record of surface water $\mathrm{pH}$ and $p \mathrm{CO}_{2}$ in the western equatorial Pacific Ocean. Science 300, 480-482.

Palmer, M.R., Pearson, P.N., Cobb, S.J., 1998. Reconstructing past ocean pH-depth profiles. Science 282, 1468-1471.

Pearce, N.J.G., Perkins, W.T., Westgate, J.A., Gorton, M.P., Jackson, S.E., Neal, C.R., Chenery, S.P. 1997. A compilation of new and published major and trace element data for NIST SRM 610 and NIST SRM 612 glass reference materials. Geostandards Newsletter: The Journal of Geostandards and Geoanalysis 21, 115-144.

Pearson, P.N., Palmer, M.R., 2000. Atmospheric carbon dioxide concentrations over the past 60 million years. Nature 406, 695-699.

Raven, J., Caldeira, K., Elderfield, H., Hoegh-Guldberg, O., Liss, P., Riebesell, U., Shepherd, J., Turley, C., Watson, A., 2005. Acidification due to increasing carbon dioxide. In Report $12 / 05$. The Royal Society of London. $60 \mathrm{pp}$.

Rink, S., Kühl, M., Bijma, J., Spero, H.J., 1998. Microsensor studies of photosynthesis and respiration in the symbiotic foraminifer Orbulina universa. Marine Biology 131 (4), 583-595

Rollion-Bard, C., Chaussidon, M., France-Lanord, C., 2003. pH control on oxygen isotopic composition of symbiotic corals. Earth and Planetary Science Letters 215 (1-2) 275-288.

Rollion-Bard, C., Vigier, N., Spezzaferri, S., 2007. In situ measurements of calcium isotopes by ion microprobe in carbonates and application to foraminifera. Chemical Geology 244, 679-690.

Rosner, M. Meixner, A, 2004. Boron isotopic composition and concentration of ten geological reference materials. Geostandards Newsletter: The Journal of Geostandards and Geoanalysis 28, 431-441.

Sanyal, A., Hemming, N.G., Hanson, G.N., Broecker, W., 1995. Evidence for a higher pH in the glacial ocean from boron isotopes in foraminifera. Nature 373, 234-236.

Sanyal, A., Hemming, N.G., Broecker, W.S., Lea, D.W., Spero, H.J., Hanson, G.N., 1996. Oceanic $\mathrm{pH}$ control on the boron isotopic composition of foraminifera: evidence from culture experiments. Paleoceanography 11 (5), 513-517.

Sanyal, A., Nugent, M., Reeder, R.J., Bijma, J., 2000. Seawater pH control on the boron isotopic composition of calcite: evidence from inorganic calcite precipitation experiments. Geochimica et Cosmochimica Acta 64 (9), 1551-1555.

Sanyal, A., Bijma, J., Spero, H.J., Lea, D., 2001. Empirical relationship between pH and the boron isotopic composition of Globigerinoides sacculifer: implications for the boron isotope paleo-pH proxy. Paleoceanography 16 (5), 515-519.

Schmidt, D.N., Kasemann, S.A., 2006. Biology of boron isotopes in planktic foraminifers: new understanding based on in situ analysis (SIMS). Geochimica et Cosmochimica Acta 70 (18), A562.

Schmidt, D.N., Elliott, T., Kasemann, S., 2008. The influences of growth on planktic foraminifers as proxies for palaeostudies. In: James, R.H Austin, W.E. N Clarke, LJ Rickaby, R.E.M. (Eds.), Biogeochemical Controls on Palaeoceanographic Proxies. Geological Society of London, London, pp. 73-85.

Spivack, A.J., Edmond, J.M., 1987. Boron isotope exchange between seawater and the oceanic-crust. Geochimica et Cosmochimica Acta 51 (5), 1033-1043.

Spivack, A.J., You, C.F., 1997. Boron isotopic geochemistry of carbonates and pore waters, Ocean Drilling Program Site 851. Earth and Planetary Science Letters 152 (1-4), 113-122.

Spivack, A.J., You, C.-F., Smith, H.J., 1993. Foraminiferal boron isotope ratios as a proxy for surface ocean pH over the past 21 Myr. Nature 363, 149-151.

Steele, I.M., Hervig, R.L., Hutcheon, I.D., Smith, J.V., 1981. In microprobe techniques and analyses of olivine and low-Ca pyroxene. American Mineralogist 66, 526-546.

Swart, P.K., 1990. Calibration of the ion microprobe for the quantitative determination of strontium, iron, manganese and magnesium in carbonate minerals. Analytical Chemistry 62, 722-728.

Tonarini, S., Pennisi, M., Adorni-Braccesi, A., Dini, A, Ferrara, G., Gonfiantini, R Wiedenbeck, M., Gröning, M., 2003. Intercomparison of boron isotope and concentration measurements. Part 1: selection, preparation and homogeneity tests of the intercomparison materials. Geostandards Newsletter: The Journal of Geostandards and Geoanalysis 27 (1), 21-39. 
Tudhope, A.W., Buddemeier, R.W., Chilcott, C.P., Berryman, K.R., Fautin, D.G., Jebb, M. Lipps, J.H., Pearce, R.G., Scoffin, T.P., Shimmield, G.B., 2000. Alternating seismic uplift and subsidence in the late Holocene at Madang, Papua New Guinea: evidence from raised reefs. Journal of Geophysical Research-Solid Earth 105, 13797-13807.

Tudhope, A.W., Chilcott, C.P., McCulloch, M.T., Cook, E.R., Chappell, J., Ellam, R.M. Lea, D.W., Lough, J.M., Shimmield, G.B., 2001. Variability in the El Nino-Southern oscillation through a glacial-interglacial cycle. Science 291, 1511-1517.

Vengosh, A., Starinsky, A., Kolodny, Y., Chivas, A.R., 1991. Boron-isotope geochemistry as a tracer for the evolution of brines and associated hot springs from the Dead Sea, Israel. Geochimica Cosmochimica Acta 55, 1689-1695.

Vigier, N., Rollion-Bard, C., Spezzaferri, S., Brunet, F., 2007. In situ measurements of isotopes in foraminifera. Geochemistry Geophysics Geosystems 8. doi:10.1029/ 2006GC001432.

Wara, M.W., Delaney, M.L., Bullen, T.D., Ravelo, A.C., 2003. Possible roles of pH, temperature and partial dissolution in determining boron concentrations and isotopic composition in planktonic foraminifera. Paleoceanography 18 (4), 1100. doi:10.1029/2002PA000797.
Wolf-Gladrow, D.A., Bijma, J., Zeebe, R.E., 1999. Model simulation of the carbonate chemistry in the microenvironment of symbiont bearing foraminifera. Marine Chemistry 64, 181-198.

Zeebe, R.E., Sanyal, A., Ortiz, J.D., Wolf-Gladrow, D.A., 2001. A theoretical study of the kinetics of the boric acid-borate equilibrium in seawater. Marine Chemistry 73 (2), 113-124.

Zeebe, R.E., Wolf-Gladrow, D.A., Bijma, J., Hönisch, B., 2003. Vital effects in foraminifera do not compromise the use of $\delta^{11} \mathrm{~B}$ as a paleo-pH indicator: evidence from modelling. Paleoceanography 18, 1043. doi:10.1029/2003PA000881.

Zeebe, R.E., Bijma, J., Hönisch, B., Sanyal, A., Spero, H.J., Wolf-Gladrow, D.A., 2008. Palaeoceanographical proxy relationships in foraminifera. Vital Effects and Beyond: A Modelling Perspective on DevelopingGeological Society London, Special Publications, vol. 303, pp. 45-58. 